\title{
Prediction of non-recoverable collapse in Eucalyptus globulus from near infrared scanning of radial wood samples
}

Maximilian Wentzel-Vietheer, Russell Washusen, Geoffrey M. Downes, Christopher Harwood, Nicholas Ebdon, Barbara Ozarska, Thomas Baker

M. Wentzel-Vietheer, R. Washusen, B.Ozarska, T. Baker

Department of Forest and Ecosystem Science, Melbourne School of Land and Environment

The University of Melbourne

500 Yarra Boulevard, Richmond, Victoria 3121, Australia

E-mail: maximilian.wentzel@gmail.com

G. Downes, C. Harwood

CSIRO Ecosystem Sciences

Private Bag 12, Hobart, Tasmania 7001, Australia

N. Ebdon

CSIRO Materials Science and Engineering

Private Bag 33, Clayton South, Victoria 3169, Australia

M. Wentzel-Vietheer, R. Washusen, G. Downes, C. Harwood, T. Baker

Cooperative Research Centre for Forestry

Private Bag 12, Hobart, Tasmania 7001, Australia 


\section{Abstract}

Near infrared (NIR) spectroscopy calibrations was used to predict radial profiles of cellulose content, wood density, cellulose microfibril angle (MFA) and modulus of elasticity (MOE) in 20-year-old plantation Eucalyptus globulus to identify non-recoverable collapse zones associated with tension wood.

Radial (cambium-to-pith) wood cores were extracted at a height of $1.0 \mathrm{~m}$ from trees selected to represent a range of silvicultural treatments. Near Infrared (NIR) spectra were measured at $1 \mathrm{~mm}$ intervals along the radial-longitudinal face of each core after drying to $12 \%$ equilibrium moisture content (EMC) at $40^{\circ} \mathrm{C}$. Tangential shrinkage was measured at 8 points along each core, following steam reconditioning and re-drying to $12 \% \mathrm{EMC}$.

Additional cores from 20 of the sample trees were collected. Radial profiles of density, MFA and MOE were obtained for wood strips prepared from these cores, using the SilviScan 3 wood assessment system. Trait profiles were matched to radial NIR scans of these cores, enabling the development of NIR calibrations using Partial Least Squares (PLS) regression. These, and an existing NIR calibration for cellulose content, were used to predict the radial profiles of the four wood properties for the first set of cores. Predicted wood properties were then related to actual tangential shrinkage measurements and the occurrence of visible bands of non-recoverable collapse.

A regression model was developed to reliably predict regions of non-recoverable collapse from NIR-predicted cellulose content and MOE. Micrography of stained wood sections indicated that the collapse was caused by the presence of tension wood.

\section{Vorhersage von nicht rückverformbarem Kollaps in radialen Eucalyptus globulus Prüfkörpern mittels Nah-Infrarot-Spektrometrie}

\section{Zusammenfassung}

Mittels NIR-Spektroskopie wurden radiale Profile des Zellulosegehalts, der Holzdichte, des Cellulose-Mikrofibrillenwinkels (MFA) und des Elastizitätsmoduls (MOE) von 20 Jahre alten Plantagen-Eucalyptus globulus erstellt, um nicht rückverformbare Kollapsbereiche in Verbindung mit Zugholz zu erkennen.

Radiale Bohrkerne (vom Kambium zur Markröhre) wurden aus Bäumen, die verschiedene waldbauliche Behandlungsverfahren repräsentieren, in 1,0 m Höhe entnommen. Nah-Infrarot (NIR)-Spektren wurden entlang der radialen/longitudinalen Fläche eines jeden Kerns in $1 \mathrm{~mm}$ Abständen gemessen, nachdem diese bei $40^{\circ} \mathrm{C}$ auf eine Gleichgewichtsfeuchte (ECM) von $12 \%$ getrocknet worden waren. Nach Dampfkonditionierung und erneuter Trocknung auf $12 \%$ EMC wurde das tangentiale Schwindmaß an acht Stellen entlang eines jeden Kerns gemessen.

Aus 20 der untersuchten Bäume wurden zusätzliche Kerne entnommen. Radiale Dichte-, MFA- und MOE-Profile wurden an Holzstreifen aus diesen Kernen mittels des Holzanalysegeräts SilviScan 3 erstellt. Aus den Eigenschaftsprofilen und den radialen NIR-Scans dieser Kerne wurden mittels partieller Regression NIR-Kalibrierungen entwickelt. Diese sowie eine bestehende NIR-Kalibrierung des Zellulosegehalts wurden zur Bestimmung der radialen Profile der vier Holzeigenschaften des ersten Kernkollektivs verwendet. Die so bestimmten Holzeigenschaften wurden dann mit den aktuell gemessenen tangentialen Schwindmaßen und dem Auftreten sichtbarer Banden von nicht rückverformbarem Kollaps in Beziehung gebracht. 
Es wurde ein Regressionsmodell entwickelt, mit dem die Bereiche mit nicht

rückverformbarem Kollaps aus dem mittels NIR bestimmten Cellulosegehalt und dem Elastizitätsmodul zuverlässig bestimmt werden können. Mikroskopische Aufnahmen gefärbter Holzabschnitte wiesen darauf hin, dass der Kollaps durch das Auftreten von Zugholz verursacht wurde. 


\section{Introduction}

Most Eucalyptus globulus plantations, which total more than 2 million ha worldwide, are managed on short (10- to 15-year) clearfall rotations to produce pulpwood (Potts et al. 2004), but there is increasing interest in managing plantations of this species for sawn timber and engineered wood products. However, processing E. globulus for these solid wood products can be compromised by the presence of tension wood. Tension wood produces high longitudinal growth stresses when it occurs at the stem periphery (Wahyudi et al. 1999; Washusen et al. 2003), causing log splitting and excessive distortion, poor sawing accuracy and board splitting, all of which reduce green board recovery. Bands of tension wood within the log cause non-recoverable collapse and high and variable transverse and longitudinal shrinkage during drying (Touza Vázquez 2001; Washusen 2009). This reduces the recovery and value of dried sawn products.

As defined by the International Association of Wood Anatomists Committee on Nomenclature (IAWA 1964), tension wood is characterized by the presence of an internal gelatinous layer in the fibres and an unlignified cell wall. The high shrinkage associated with tension wood that occurs during drying appears similar to collapse in normal wood, however, with the application of steam reconditioning these zones do not recover their original dimensions (Boyd 1977; Chafe et al. 1992; Kauman 1964). Washusen (2000) reported a comprehensive anatomical study of $E$. globulus wood which described non-recoverable collapse and confirmed the presence of associated tension wood by microscopic examination of stained wood sections.

In most hardwood tree species, tension wood occurs when trees reposition their stem orientation to capture light as the stand develops, or in response to bending stresses applied by factors such as prevailing winds (Kubler 1988; Scurfield 1973). However, in some species, for example Acacia mangium and E. globulus, even apparently straight trees can develop tension wood (Wahyudi et al. 1999; Washusen and llic 2001). Tension wood was predominantly restricted to the lower $30 \%$ of tree height and increased in severity towards the base in straight trees in an 11-year-old E. globulus plantation in South Australia (Washusen 2002). The impact of tension wood on wood shrinkage depends on the frequency and distribution of tension wood fibres. In core samples from this plantation, when the percentage of tension wood fibres with thick gelatinous layers exceeded $10 \%$ over a $5 \mathrm{~mm}$ radial distance, there were identifiable zones of excessive shrinkage after reconditioning (Washusen and Ilic 2001).

Detection of tension wood by microscopic observation on the anatomy of xylem cells in stained wood sections is time-consuming, labour-intensive, and therefore expensive. Indirect methods that analyse wood physical and/or chemical properties at fine scale offer the prospect of detecting tension wood more rapidly and at lower cost. This would facilitate 
systematic studies to evaluate the effects of site, silviculture and genetics on the occurrence of tension wood in E. globulus plantations managed for solid and engineered wood products. Tension wood is characterized by high cellulose content, low cellulose microfibril angle (MFA), high basic density and high modulus of elasticity (MOE) (Chaffey 2000; Chauhan and Walker 2011; Wada et al. 1995; Wardrop and Dadswell 1955).

The SilviScan wood microstructure assessment system combines scanning X-ray microdensitometry and X-ray diffraction to measure wood properties in prepared wood strips of $2 \mathrm{~mm}$ thickness. It has been used to determine the radial profile, at fine scale, of wood density, MOE and MFA (Evans 1994, 1999; Evans and Ilic 2001; Evans et al. 2000). Previous versions of SilviScan had been configured to measure cellulose crystallite width, which is an indicator of tension wood (Washusen and Evans $2001 \mathrm{~b})$. Maximum values of crystallite width greater than $3.6 \mathrm{~nm}$ are associated with the presence of tension wood (Washusen and Evans 2001a).

The effects of silvicultural treatments on the development of tension wood in an E. globulus plantation trial in Gippsland, Victoria were investigated using SilviScan. Radial profiles of cellulose crystallite width and MFA in 13-year-old trees were examined (Washusen et al. 2005). Tension wood, indicated by high crystallite width and low MFA, was found to be more prevalent in the treatments that had been heavily thinned to 200 trees $^{-1}$ at age 8 years than in unthinned and less heavily thinned treatments, but its occurrence was reduced by the application of fertilizer at thinning.

The association of wood chemical and physical properties with tension wood suggests that near infrared (NIR) spectroscopy could be used to detect tension wood occurrence. Diffuse reflectance NIR spectra consist mainly of overtone and combination bands corresponding to the fundamental stretching vibrations of $\mathrm{O}-\mathrm{H}, \mathrm{N}-\mathrm{H}$ and $\mathrm{C}-\mathrm{H}$ functional groups and reflect the chemistry of the sample (Michell 1995; Næs et al. 2002). NIR spectra can be collected from solid wood cores, wood meal, wood strips or wood chips. Regression calibrations are developed to associate particular wood properties with the spectra, for an appropriate sample population (Thomas 1994).

NIR spectroscopy has been used to predict wood cellulose content. A global NIR calibration for cellulose content was developed based on chemically analysed samples of wood meal from over 1800 samples from a number of Eucalyptus species (Downes et al. 2010). This global wood meal cellulose calibration was used to build a calibration to predict cellulose content based on spectra collected from the radial longitudinal surface (Downes et al. 2012). These calibrations displayed high explanatory power and low error when applied to a wide range of eucalypt samples. For example, the surface scanning calibration developed for E. globulus has an $r^{2}$ (percentage of variance explained) of $86 \%$ and root mean square error of cross validation (RMSECV) of $0.87 \%$ cellulose content (Downes et al. 2012). NIR calibrations to predict microfibril angle (MFA) in Pinus radiata and $P$. taeda (Schimleck et al. 2005b), basic 
density in E. globulus (Schimleck et al. 1999) and modulus of elasticity (MOE) in $E$. delegatenis and $P$. radiata (Schimleck et al. 2002) have also been developed. SilviScan (Evans 1994) MFA and MOE data was used to build these NIR calibrations (Schimleck et al. 2005a). However, NIR calibrations for density, MFA and MOE developed to date have displayed lower levels of explanatory power compared to those for cellulose. This is to be expected, because variations in density, MFA and MOE are less directly related to basic wood chemistry and associated NIR spectra than is variation in cellulose content.

Low MFA and high cellulose content, density and MOE are known characteristics that are related to non-recoverable collapse, and it has been demonstrated that these wood properties can be predicted from NIR spectra. The study reported here examined whether bands of nonrecoverable collapse in E. globulus could be reliably predicted from radial profiles of these wood properties, predicted by radial NIR surface scanning.

\section{Materials and Methods}

\section{Eucalyptus globulus plantation}

Wood samples were collected from trees in an E. globulus silvicultural trial near Tostaree, Victoria, Australia $\left(37.78^{\circ} \mathrm{S}, 148.18^{\circ} \mathrm{E}\right)$. The trial had been established to investigate the effects of silvicultural treatments on tree growth and log yield, and tension wood occurrence in the stand had been studied previously (Washusen et al. 2005).

The trial was planted in 1991 using E. globulus ssp. globulus seedlings (Waitawhile Track, Otway Ranges, Victoria seed source) at a spacing of $3.5 \times 2.5 \mathrm{~m}$ (1143 trees ha- $\left.{ }^{-1}\right)$. The trial tested three thinning treatments (unthinned control (UT), and non-commercial thinning at age 8 years with residual stockings of 400 trees ha $^{-1}$ (NCT400) and 200 trees ha $^{-1}$ (NCT200) in factorial combination with two levels of fertilizer application at thinning (no fertilizer, and fertilizer providing 200, 62.5, 62.5 and $6 \mathrm{~kg} \mathrm{ha}^{-1}$ of $\mathrm{N}, \mathrm{P}, \mathrm{K}$ and $\mathrm{S}$, respectively).

\section{Sampling}

The trees were sampled at age 20 years. From measurements of all trees in the silvicultural trial at this age, average diameters (over bark at $1.3 \mathrm{~m}$ height; $\left.\mathrm{DOB}_{1.3}\right)$ increased from UT $(29.5 \mathrm{~cm}), \mathrm{NCT} 400(30.3 \mathrm{~cm})$, to NCT200 $(31.2 \mathrm{~cm})$, with little effect of fertilizer on $\mathrm{DOB}_{1.3}$.

Potential sample trees (live, single-stemmed, with less than $20^{\circ}$ buttsweep) were initially identified from the inventory of all trees within the trial to select matched sets of trees spanning a comparable diameter range $\left(\mathrm{DOB}_{1.3} 25-35 \mathrm{~cm}\right)$ across different silvicultural treatments $(6$ treatments $\mathrm{x}$ 18 trees), and additionally trees representing the wider diameter range in each treatment. In total, 180 trees were sampled (Table 1), but only 175 
wood cores were used, because 5 cores broke during initial laboratory processing.

Radial, bark-to-pith, $12 \mathrm{~mm}$ diameter increment cores were taken from the south-western aspect of the sampled trees at $\sim 1.0 \mathrm{~m}$ height. The southwestern aspect was chosen because previous research on the within-tree distribution of tension wood at this site (Washusen et al. 2002) had indicated that tension wood was likely to be most prevalent at this aspect, consistent with strong winds being predominantly from the west and southwest.

The cores were taken using a motorized wood corer. Wood cores were discarded if they contained a knot or kino pocket, and a replacement core was taken from the same aspect of the same tree at $\sim 0.9 \mathrm{~m}$ height. The first set of wood cores was taken in February 2011. The second set of wood cores was collected in July 2011 from a subset of these trees that were judged likely to display non-recoverable collapse based on preliminary predictions of wood properties and measurements of tangential shrinkage from the first set. The second set of cores was taken from the south-western aspect of the trees at $\sim 0.9 \mathrm{~m}$ height.

\section{Tangential shrinkage measurements}

The first set of cores was planed on both longitudinal-radial faces to facilitate shrinkage measurements and NIR scanning. Tangential width measurements were made on every core using a digital spindle micrometer (Mitutoyo micrometer series 331-261). The micrometer had a range of $0-25 \mathrm{~mm}$, a graduation of $0.001 \mathrm{~mm}$, a $2 \mathrm{~mm}$ diameter anvil and spindle, and a ratchet stop to apply a constant force. The micrometer recorded measurements directly to a computer.

Green cores were delimited at $25 \%, 50 \%$ and $75 \%$ of their bark-to-pith length, dividing the core into four quarters. The mid-points of each quarter were marked (Fig1). Tangential widths and distances from bark were measured at each mid-point in the green condition, and the cores weighed.

The cores were dried as recommended by Washusen (2000), inside a laboratory kiln at a dry bulb temperature of $40^{\circ} \mathrm{C}$ and a wet-bulb temperature of $34.5^{\circ} \mathrm{C}$. Samples were dried over 3 days to constant weight, corresponding to equilibrium moisture content (EMC) of about $12 \%$. After drying, the cores were placed in a conditioning room (relative humidity $66.6 \%$ and temperature $22.5^{\circ} \mathrm{C}$ ) to maintain $12 \%$ EMC.

The tangential width of the cores was re-measured at the marked midpoints of each quarter. In addition, the width at the point of observed maximum tangential shrinkage was measured in each quarter. That is, a total of 8 tangential widths were measured per core. The points of maximum tangential shrinkage were marked with a cross using a waterproof pencil (Fig2). 
Tangential shrinkage at each mid-point and at the maximum shrinkage point in each quarter of the cores (relative to green condition) was measured again after reconditioning using a water vapour saturated air stream $\left(95-100^{\circ} \mathrm{C}\right)$ for two hours followed by re-drying to about $12 \% \mathrm{MC}$. The cores were then oven dried at $103+/-2^{\circ} \mathrm{C}$, tangential shrinkage remeasured and oven dry weights measured to calculate the moisture content after reconditioning. Shrinkage values were normalized to $12 \%$ moisture content (MC) by using measured $\mathrm{MC}$ for each core in the following equation:

where:

$\mathrm{T}_{\mathrm{a}}$ is the adjusted tangential shrinkage after reconditioning $(\mathrm{mm})$;

$\mathrm{T}_{\mathrm{mar}}$ is the measured tangential shrinkage after reconditioning $(\mathrm{mm})$;

$\mathrm{T}_{\mathrm{mod}}$ is the measured tangential shrinkage after oven drying $(\mathrm{mm})$;

$\mathrm{MC}_{\mathrm{ar}}$ is the moisture content of the core after reconditioning (\%), and $\mathrm{MC}_{12 \%}$ is the moisture content of the core at $12 \%$.

The average of the four mid-point core widths prior to drying was used to calculate shrinkage at the points of maximum shrinkage (i.e. where widths were not measured before drying because the points had not yet been identified). The average standard deviation of all green mid-point tangential widths was $0.006 \mathrm{~mm}$, small compared to the average width difference from green to dry condition $(1.2 \mathrm{~mm})$.

\section{SilviScan analysis}

The second set of cores collected for SilviScan analysis was dehydrated in ethanol (Evans et al. 2000) for 1 week. The cores were then conditioned in a room at $20^{\circ} \mathrm{C}$ and $40 \%$ humidity until their weight was constant. The moisture content of the samples was about $8 \%$.

The cores were cut to produce radial strips, $2 \mathrm{~mm}$ tangentially and $7 \mathrm{~mm}$ longitudinally (Evans 1994, 1999) using an adjustable twin-blade saw. The samples were analysed, commencing at the cambial end, using SilviScan3 (Evans 1999, 2006; Evans et al. 2000). SilviScan measurements of MFA, density and MOE were obtained for all 20 cores, at $1 \mathrm{~mm}$ intervals.

\section{NIR spectroscopy}

NIR diffuse reflectance spectra were measured on one radial longitudinal face of each core dried to $12 \% \mathrm{MC}$ prior to reconditioning, for the set of 175 samples used to measure tangential shrinkage, and for the 20 SilviScan strips.

A Bruker MPA FT-NIR spectrometer (Bruker Optik GmbH, Ettlingen, Germany) with a built in fibre-optic scanning attachment joined to a linear sample transport system was used to measure spectra at $1 \mathrm{~mm}$ intervals from bark to pith. The wave number range was between $10,000 \mathrm{~cm}^{-1}$ and 
$4,000 \mathrm{~cm}^{-1}$ (between $1000 \mathrm{~nm}$ and $2500 \mathrm{~nm}$ ) at an $8 \mathrm{~cm}^{-1}$ resolution. Each spectrum was an average of 16 scans.

\section{Calibration development}

Using the data obtained from the SilviScan analyses and the respective spectra from the set of 20 cores, calibrations for MFA, density and MOE were developed. Each NIR and SilviScan sampling interval was obtained relative to the cambial end enabling matching of each SilviScan data point to the corresponding NIR spectrum. The QUANT software (Bruker 2005) was used, employing partial least squares (PLS) regression (Næs et al. 2002). Statistical parameters including the coefficient of determination $\left(R^{2}\right)$, root mean square error of the cross validation (RMSECV) and the number of principal components required (rank) were obtained for each calibration. All the SilviScan data available for each property (MFA, density, MOE) was used with the corresponding NIR spectra.

\section{Predictions}

In addition to the NIR calibrations for density, MFA and MOE, a previously developed cellulose calibration was applied to the spectra sets from the 175 wood cores before reconditioning, to predict these wood properties at $1 \mathrm{~mm}$ intervals. The cellulose calibration had been developed with NIR spectra obtained at $1 \mathrm{~mm}$ increments and then averaged to $10 \mathrm{~mm}$ intervals, so that the data could be matched to laboratory diglyme cellulose analyses (Downes et al. 2012). No laboratory cellulose validation was done on the samples used in this study.

\section{Statistical analysis}

At each measured tangential shrinkage point the distance from bark to pith was determined to match with the appropriate spectra from which cellulose content, MFA, density and MOE were predicted. For example, in core No. 001 (Table 2), the first measurement of tangential shrinkage was $21 \mathrm{~mm}$ from the bark. This was the original reference point in the quarter closest to the bark and the predicted wood properties from the associated NIR spectrum were matched to the measurement point. Table 2 shows the NIR predictions for the eight $1 \mathrm{~mm}$ scans of core No 001 that correspond with the eight marked points where tangential shrinkage after reconditioning was measured.

To give better representation to sites of non-recoverable collapse in the analysis, a data set was selected using stratification and accrual methods so that the tangential shrinkage had equal representation across the shrinkage range. This was done because points of high shrinkage after reconditioning that indicated tension wood presence were relatively few and the bulk of the data were considered to be within the shrinkage range for normal wood. The data were firstly allocated to 8 stratum cells, each with a shrinkage range of $2.5 \%$. Data points were then randomly selected from the whole data set until 10 points were accrued for each shrinkage range. As there were only 9 sample points with shrinkage over $20 \%$, this stratum cell only had 9 points, thus making the total number of shrinkage 
points chosen 79 . This set was termed the equally weighted shrinkage data set. The second set included all of the tangential shrinkage points and therefore had far greater representation of normal wood. It was termed the full data set. Pearson correlations (Edwards 1976) were calculated for each data set to determine correlations between NIRpredicted wood properties and tangential shrinkage after reconditioning.

NIR-predicted wood quality traits that were significantly correlated with tangential shrinkage were included in a forward stepwise regression to predict tangential shrinkage after reconditioning, using IBM SPSS Statistics software version 19. Tests for both data sets were conducted for heteroscedasticity (Breusch and Pagan 1979) with the same software.

The best model developed from the regression analysis was applied to all the spectra obtained from the 175 core samples data set to analyse the strength in predicting tangential shrinkage across whole cores and to examine the correspondence between high predicted tangential shrinkage and measured non-recoverable collapse.

\section{Histochemical analysis}

To test whether the non-recoverable collapse was associated with tension wood, histochemical tests were conducted on anatomical sections taken from selected samples that presented non-recoverable collapse.

The transverse sections of the cores were cut into $1.5 \mathrm{~cm}$ long pieces in the radial direction with the non-recoverable collapse zones in the middle of the section. To differentiate between normal and tension wood fibres, a double staining procedure was conducted using a combination of safranin and alcian blue.

Sections of $18 \mu \mathrm{m}$ thickness were cut using a microtome (American Optical Company Sliding Microtome) and firstly stained with $1 \%$ aqueous safranin and counter stained with $1 \%$ aqueous alcian blue. The samples were then viewed in a microscope (Olympus BX61 motorized microscope) with a camera attached to obtain digital images using the AnalySIS Pro Image software.

\section{Results}

\section{Tangential shrinkage after reconditioning}

The mean tangential shrinkage after reconditioning was 9.3\%. Samples that had measured shrinkages $>15 \%$ presented distorted surfaces and a visible collapse that can be described as non-recoverable, as the steam reconditioning had little or no effect on dimension recovery. In contrast, samples with tangential shrinkage values $<15 \%$ exhibited normal shrinkage as there were no visible signs of collapsed surfaces. Sample points, either at the marked mid-points or the points of maximum shrinkage (Fig2), that had tangential shrinkage $>15 \%$ comprised $3 \%$ of all the measurements (40 out of 1,386), but were present in $16 \%$ of the cores (28 out of 175). 
Cores with maximum shrinkage exceeding $15 \%$ occurred in all six silvicultural treatments at approximately equal frequencies. Fertilizer application did not significantly affect the incidence of non-recoverable collapse (36\% of the cores exhibiting non-recoverable collapse came from treatments without fertilizer). Table 3 shows the number of trees in each treatment having at least one instance of non-recoverable collapse in a core.

The measured points where tangential shrinkage exceeded $15 \%$ were used as reference points to assess whether the values of NIR-predicted cellulose content, MFA, density and MOE could be used to identify zones of tension wood.

\section{Measurement of wood properties using SilviScan}

Mean SilviScan density for the 20 cores selected for development of the calibrations was $783 \mathrm{~kg} \mathrm{~m}^{-3}$, mean MFA was 10.3 and mean MOE 18.6 $\mathrm{GPa}$, although the range of individual values for all three variables was very wide (Table 4). There was a moderate negative relationship between MFA and density $(r=-0.66)$.

\section{NIR-based predictions of wood properties}

Cross-validation models for the radial scanning calibrations are shown in Fig.3. The component ranges for each property were; $2^{\circ}-33.8^{\circ}$ MFA, 292 $-1216 \mathrm{~kg} \mathrm{~m}^{-3}$ density and $5.3-36.7 \mathrm{GPa}$. The calibrations explained $62.8 \%, 64 \%$ and $73.8 \%$ of the variation in MFA, density and MOE respectively and the RMSECV was $2.42^{\circ}$ for MFA, $96.3 \mathrm{~kg} \mathrm{~m}^{-3}$ for density and 3.0 GPa for MOE.

These calibrations, along with the existing calibration for cellulose content, were used to generate NIR-predicted radial profiles (Fig.4) of these properties for the first sample set of 175 wood cores. The range of predicted cellulose content varied from $35 \%$ to $60.6 \%$ with a mean of $43.8 \%$. Cellulose content tended to generally increase from the pith to the cambium. The predicted MFA varied between $1^{\circ}$ and $39^{\circ}$ with a mean of $12^{\circ}$. This was higher than the average from the Tostaree SilviScan data calibration $\left(10.3^{\circ}\right)$.

The minimum predicted density was $177 \mathrm{~kg} \mathrm{~m}^{-3}$ and the maximum $1252 \mathrm{~kg} \mathrm{~m}^{-3}$. Predictions below $600 \mathrm{~kg} \mathrm{~m}^{-3}$ were obtained from the pith ends of the samples in most of the cores. The mean predicted density was $766 \mathrm{~kg} \mathrm{~m}^{-3}$, which was lower than the average density from the Tostaree calibration sample set $\left(783 \mathrm{~kg} \mathrm{~m}^{-3}\right)$.

The predicted MOE presented some unusually low values, which were related to unusually high MFA predictions and very low cellulose percentages, both properties that are biologically related to MOE. Negative values and values less than $5 \mathrm{GPa}$ were discarded. The mean measurement was 17.6 GPa, slightly lower than the values obtained in the Tostaree calibration (18.2 GPa). 
Out of the 175 samples, 30 showed very low MFA and high predictions for density and MOE at one or more points along the sample.

\section{Relationships between predicted wood properties and tangential shrinkage}

The predicted cellulose content, MFA, density and MOE were examined in cores in which tangential shrinkage over $15 \%$ occurred at one or more of the eight measured points. These zones of non-recoverable collapse (high measured shrinkage) were typically associated with high predicted cellulose content (usually over $50 \%$ ), density (above $960 \mathrm{~kg} / \mathrm{m}^{3}$ ) and MOE (above $25 \mathrm{GPa}$ ), and low predicted MFA (under $7.5^{\circ}$ ), as seen in Fig. 4, where the peaks of the predicted wood properties were related to the measured non-recoverable collapse zone in the core.

The Pearson correlation matrices for the equally weighted and full data sets are given in Tables 5 and 6. NIR-predicted cellulose content, MFA, MOE and density were all significantly correlated with shrinkage to $12 \%$ $\mathrm{MC}$ after reconditioning $(A R)$ in both data sets $(p<0.01)$. The equally weighted shrinkage data had stronger correlations with shrinkage than the full data set. There was a particularly strong correlation between shrinkage and cellulose content $(r=0.76)$. Tangential shrinkage also correlated well with MFA, density and MOE. There was a strong negative correlation between cellulose content and MFA, and a positive correlation between cellulose content and density and MOE. MFA, density and MOE were strongly inter-correlated.

\section{Stepwise regression to predict tangential shrinkage after recovery}

The stepwise regressions developed to predict tangential shrinkage are presented in Table 7. In both cases the dependant variable was tangential shrinkage at $12 \%$ moisture content after recovery.

Cellulose content was an important predictor of tangential shrinkage, especially in Model 1. MOE was also an important predictor in both models. In neither case did MFA or density add significantly to the explanatory power of the regression. A Breusch-Pagan test was performed using IBM SPSS Statistics software to test for heteroscedasticity. The results rejected heteroscedasticity at $p<0.05$, indicating that no data transformation was necessary for the regression.

Model 1 is represented by the following equation:

\section{Model 1}

where:

$\mathrm{Y}$ is the predicted tangential shrinkage to $12 \% \mathrm{MC} A R$;

$\mathrm{X}_{1}$ is the NIR-predicted cellulose content (\%); and

$\mathrm{X}_{2}$ is the NIR-predicted MOE (GPa). 
Model 1 explained $64 \%(p<0.01)$ of the variance in tangential shrinkage when applied to the equally weighted data (Fig.5) and 35\% when applied to the whole data set of measured shrinkage points (Fig.6). The vertical and horizontal lines in both graphs in Fig.5 and Fig. 6 divide the data into quadrants that indicate the capability of each model to predict bands of non-recoverable collapse, assuming a 15\% shrinkage threshold. The lower left quadrant indicates data points correctly identified as points of normal shrinkage and the quadrant at the top right indicates the data that are correctly identified as affected by non-recoverable collapse (over 15\% tangential shrinkage). The data points in the two remaining quadrants were incorrectly identified by the model as either points of normal shrinkage (upper left quadrant) or points of non-recoverable collapse (lower right quadrant). Both prediction sets had a number of errors. Model 1 correctly identified $75 \%$ of the observed points with non-recoverable collapse in the equally weighed set. In the whole data set it correctly identified $55 \%$ of these points. At the high end of the predicted shrinkage, in the equally weighed set, out of the 29 measurements of shrinkage higher than 15\%, 21 were under predicted and 8 over predicted, meanwhile from the whole set, from 40 measurements over $15 \%$, 30 were under predicted and 10 over predicted.

\section{Prediction of tangential shrinkage for the entire radial profiles}

Model 1 was applied to the NIR radial profiles from the 175 cores, to predict wood properties at $1 \mathrm{~mm}$ resolution. Model 1 predicted that more than $10 \%$ of the data points would have shrinkage of over $15 \%$ at $12 \% \mathrm{MC}$ AR.

The predicted radial profiles of tangential shrinkage were tested across individual wood cores with observed non-recoverable collapse bands to compare predicted and observed shrinkage patterns.

Fig.7 shows four examples of cores with bands of non-recoverable collapse. These cores all had measured non-recoverable collapse bands corresponding to the distinctive peaks of predicted shrinkage visible in the graphs.

\section{Histochemical analysis of tension wood presence}

Collapse zones of the four core samples shown in Fig.7 were selected for histochemical staining. Inspection of microscopic images confirmed the presence of tension wood, with cells having characteristically thick walls, small lumens and a clearly visible layer corresponding to gelatinous cellulose free of lignin, stained by alcian blue.

\section{Discussion}

It has been demonstrated that bands of non-recoverable collapse in $E$. globulus wood samples can be predicted from radial profiles of NIRpredicted wood properties determined from scanning of the radiallongitudinal wood surface after three days of drying under controlled conditions from the green to the air dry state (12\% moisture content). NIR- 
predicted cellulose content and MOE were the strongest predictors of tangential shrinkage and non-recoverable collapse. As with previous studies on E. globulus (Washusen 2000; Washusen and llic 2001), microscopy and histochemical analysis confirmed that zones of excessive non-recoverable collapse were anatomically identified as tension wood.

More work is required to determine the extent to which the NIR calibrations presented here can be extended across a range of site conditions and different eucalypt species so as to allow global calibrations for shrinkage to be developed, as has been done for prediction of cellulose content and Kraft pulp yield from woodmeal samples (Downes et al. 2011). When developing NIR calibrations for density, MFA and MOE the use of SilviScan is critical as it is the only cost-effective mean of generating the required calibration data at a suitable radial resolution $(1.0 \mathrm{~mm}$ sampling intervals).

The variance explained by NIR calibrations for density, MFA and MOE developed for this study was similar to that of other NIR calibrations for these traits in eucalypt species, such as basic density from 8 year old E. globulus (up to $R^{2}$ of 0.77 ) (Schimleck et al. 1999), MFA $\left(R^{2}\right.$ of 0.77 ) and MOE ( $R^{2}$ of 0.90$)$ in $E$. delegatensis (Schimleck et al. 2001) and MFA $\left(R^{2}\right.$ of 0.69$)$ and MOE $\left(R^{2} 0.80\right)$ in E. nitens (Schimleck et al. 2006). Published calibrations describing the prediction of wood basic density from woodmeal samples (Downes et al. 2011; Schimleck et al. 1999) and solid wood (Schimleck et al. 2003) indicate root mean square errors of prediction of $\sim 25-30 \mathrm{~kg} \mathrm{~m}^{-3}$. The calibrations presented here exhibited markedly higher standard errors. This probably arises from three sources:

Minor (less than $1 \mathrm{~mm}$ ) mis-alignment between the radial NIR spectra with the SilviScan arising from slight differences in the starting point of the two scans

Although both scans were generated at $1 \mathrm{~mm}$ intervals, the width of the NIR illuminated region was $1.08 \mathrm{~mm}$ compared with the $1 \mathrm{~mm}$ footprint for SilviScan.

Collection of NIR spectra from the radial-longitudinal surface was matched with SilviScan data generated from X-rays transmitted through the $2 \mathrm{~mm}$ tangential thickness of the strip. Where orientation of density variation caused by the annual cycle of early/late wood, associated with growth rings, is not perfectly tangential, some measurement error, from the perspective of the NIR spectra, would arise.

It is possible that developing calibrations between SilviScan and NIR using wider sampling intervals $(2-5 \mathrm{~mm})$ might reduce the significance of these potential sources of error. The application of calibrations developed at these coarser resolutions to spectra collected at finer intervals also requires investigation. However the successful development of a surfacescanning cellulose calibration for E. globulus at $10 \mathrm{~mm}$ resolution (Downes et al. 2012; Downes et al. 2010) suggests that improvements in the calibrations for density, MFA and MOE may be feasible. 
Considerable radial variation in wood properties was evident (Fig.4). Radial trends in cellulose content matched those reported by Downes et al (2012) who found that NIR-predicted cellulose content generally increased from pith to cambium for E. globulus plantations at three sites in Western Australia. In their study, a small proportion of trees had one or more distinct bands of high cellulose content and Kraft Pulp Yield, indicative of non-recoverable collapse zones. The radial increase in MOE from pith to cambium and the corresponding decline in MFA observed in the current study was consistent with that reported for 22-year-old plantation-grown E. nitens by Medhurst et al. (2012) who examined radial profiles with SilviScan.

NIR scanning of the set of 175 cores followed by shrinkage prediction using Model 1 predicted a greater number and higher proportion of sample points with non-recoverable collapse than what was measured with the microtome. This can be explained by the greater frequency of tension wood measurements in the large data set. The data used to develop Model 1 had a single measurement of shrinkage taken at the point of highest shrinkage within each collapse band. In the NIR-predicted data set, there were usually several measurement points indicating collapse within individual bands. At positions where predicted cellulose content and MOE were above $50 \%$ and $25 \mathrm{GPa}$ respectively, non-recoverable collapse was typically found.

The proportions of trees with non-recoverable collapse across the six different fertilizer and thinning treatments combinations did not differ significantly in this study. This contrasts with the findings of Washusen et al. (2005), who sampled the same plantation five years after thinning and fertilizer application and showed that fertilizer application significantly reduced the development of tension wood, as indicated by high cellulose crystallite width at high thinning intensity. In the current study here the proportions of trees with collapse were low, making it difficult to detect treatment effects through comparison of proportions of trees affected.

This method offers the prospect of being able to survey the extent of nonrecoverable collapse in standing E. globulus trees by radial NIR scanning of wood core samples, relatively quickly and at modest cost. This could be applied in studies that aim to better understand the effects of site, silviculture and genetics on the occurrence of non-recoverable collapse and associated tension wood that may limit the solid-wood utilization of this species (Washusen 2009). However, additional work is clearly required to understand the relationship between the levels of predicted occurrence of collapse in radial samples with product quality outcomes for defined wood processing systems. To cause severe drying degrade in actual boards (Touza Vázquez 2001; Washusen 2009), it is likely that predicted non-recoverable collapse bands would have to be at least $5 \mathrm{~mm}$ in radial extent; this needs to be verified experimentally. 


\section{Conclusion}

Zones of high NIR-predicted cellulose content, density and MOE, and low NIR-predicted MFA were closely associated with bands of non-recoverable collapse in radial wood samples of $E$. globulus. This was confirmed by a regression analysis indicating that bands of non-recoverable collapse could be reliably predicted from NIR-predicted cellulose content and MOE. Non-recoverable collapse occurred when cellulose content and MOE were above $50 \%$ and $25 \mathrm{GPa}$ respectively. These thresholds can be used with core sampling strategies and radial NIR scanning as a relatively low cost and effective means of identifying zones of excessive non-recoverable shrinkage associated with tension wood occurrence in E. globulus.

Acknowledgments: This study forms part of Program 2 (High Value Wood Resources) of the Cooperative Research Centre for Forestry, Australia, and was funded by the CRC Forestry and The University of Melbourne. The Tostaree plantation trial was established and maintained with support from the Victorian Department of Sustainability and Environment and the Victorian Department of Primary Industries. We thank Robert Evans for the SilviScan analysis of the samples. 


\section{References}

Boyd JD (1977) Relationship between fibre morphology and shrinkage of wood. Wood Sci Technol 11 (1):3-22.

Breusch TS, Pagan AR (1979) A simple test for heteroscedasticity and random coefficient variation. Econometrica 47 (5):1287-1294

Bruker (2005) OPUS Spektroskopiesoftware. QUANT Ver. 5.5. edn. BRUKER OPTIK $\mathrm{GmbH}$, Ettlingen, Germany

Chafe SC, Barnacle JE, Hunter AJ, llic J, Northway R, Rozsa AN (1992) Collapse: An Introduction. CSIRO Divison of Forestry and Forest Products, Melbourne

Chaffey N (2000) Microfibril orientation in wood cells: new angles on an old topic. Trends in Plant Science 5 (9):360-362

Chauhan SS, Walker J (2011) Wood quality in artificially inclined 1-year-old trees of Eucalyptus regnans - differences in tension wood and opposite wood properties. Canadian Journal of Forest Research 41 (5):930-937.

Downes G, Harwood C, Weidemann J, Ebdon N, Bond H, Meder R (2012) Radial variation in Kraft pulp yield and cellulose content in Eucalyptus globulus wood across three contrasting sites predicted by near infrared spectroscopy. Canadian Journal of Forest Research 42 (8):1577-1586.

Downes G, Meder R, Ebdon N, Bond H, Evans R, Joyce K, Southerton S (2010) Radial variation in cellulose content and Kraft pulp yield in Eucalyptus nitens using near-infrared spectral analysis of air-dry wood surfaces. Journal of Near Infrared Spectroscopy 18 (2):147-155

Downes GM, Meder R, Bond H, Ebdon N, Hicks C, Harwood C (2011) Measurement of cellulose content, Kraft pulp yield and basic density in eucalypt woodmeal using multisite and multispecies near infra-red spectroscopic calibrations. Southern Forests: A Journal of Forest Science 73 (3/4):181-186.

Edwards AL (1976) An introduction to linear regression and correlation. W. H. Freeman, San Francisco, California

Evans R (1994) Rapid measurement of the transverse dimensions of tracheids in radial wood sections from Pinus radiata. Holzforschung 48 (2):168-172

Evans R (1999) A variance approach to the X-ray diffractometric estimation of microfibril angle in wood. Appita journal 52 (4):283-289

Evans R (2006) Wood stiffness by x-ray diffractometry. In: Stokke DD, Groom LH (eds) Characterization of the Cellulosic Cell Wall. Blackwell Publishing, Oxford, pp 138-146.

Evans R, llic J (2001) Rapid prediction of wood stiffness from microfibril angle and density. For Prod J 51 (3):53-57

Evans R, Stringer S, Kibblewhite R (2000) Variation of microfibril angle, density and fibre orientation in twenty-nine Eucalyptus nitens trees. Appita journal 53 (6):450-457

IAWA (1964) Multilingual glossary of terms used in wood anatomy. Verlagsanstalt Buchdruckerei Konkordia, Winterhur

Kauman WG (1964) Cell collapse in wood - 1. Process variables and collapse recovery. Holz Roh- Werkst 22 (5):183-196

Kubler H (1988) Silvicultural Control of Mechanical Stresses in Trees. Canadian Journal of Forest Research 18 (10):1215-1225

Medhurst J, Downes G, Ottenschlaeger M, Harwood C, Evans R, Beadle C (2012) Intraspecific competition and the radial development of wood density, microfibril angle and modulus of elasticity in plantation-grown Eucalytus nitens. Trees 26 (6): 1771-1780. Michell AJ (1995) Pulpwood quality estimation by near-infrared spectroscopic measurements on eucalypt woods. Appita journal 48:425-428

Næs T, Isaakson T, Fearn T, Davies T (2002) A User-friendly Guide to Multivariate Calibration and Classification. NIR Publications, Chichester, UK

Potts B, Vaillancourt R, Jordan G, Dutkowski G, McKinnon G, Steane D, Volker P, Lopez G, Apiolaza L, Li Y (2004) Exploration of the Eucalyptus globulus gene pool. . In: Eucalyptus in a changing world. Proc. IUFRO Conference Aveiro, 11-15 October. (RAIZ, Instituto Investigaciao de Floresta e Papel, Portugal). pp 46-61

Schimleck L, Downes G, Evans R (2006) Estimation of Eucalyptus nitens wood properties by near infrared spectroscopy. Appita journal 59 (2):136-141

Schimleck L, Evans R, Ilic J (2001) Estimation of Eucalyptus delegatensis wood properties by near infrared spectroscopy. Canadian Journal of Forest Research 31 (10):1671-1675 
Schimleck L, Evans R, llic J, Matheson AC (2002) Estimation of wood stiffness of increment cores by near-infrared spectroscopy. Canadian Journal of Forest Research 32 (1):129-135

Schimleck L, Evans R, Jones PD, Daniels RF, Peter GF, Clark A (2005a) Estimation of microfibril angle and stiffness by near infrared spectroscopy using sample sets having limited wood density variation. IAWA Journal 26 (2):175-187

Schimleck L, Jones D, Peter G, Daniels R, Clark A (2005b) Success in using near infrared spectroscopy to estimate wood properties of Pinus taeda radial strips not due to autocorrelation. Journal of Near Infrared Spectroscopy 13 (1):47-52

Schimleck L, Michell A, Raymond C, Muneri A (1999) Estimation of basic density of Eucalyptus globulus using near-infrared spectroscopy. Canadian Journal of Forest Research 29 (2):194-201

Schimleck L, Mora C, Daniels RF (2003) Estimation of the physical wood properties of green Pinus taeda radial samples by near infrared spectroscopy. Can J For Res-Rev Can Rech For 33 (12):2297-2305

Scurfield G (1973) Reaction Wood - Its structure and Function. Science 179 (4074):647655

Thomas, E. V. 1994. A primer on Multivariate Calibration. Analytical Chemistry, 66 (15): A795-A804.

Touza Vázquez MC (2001) Growth stresses in Eucalyptus globulus from Galicia (Spain). Influences and sawing strategies. (In Spanish) Maderas Ciencia y tecnología 3 (1-2):6889

Wada M, Okano T, Sugiyama J, Horii F (1995) Characterization of tension and normally lignified wood cellulose in Populus maximowiczii. Cellulose 2 (4):223-233. Wahyudi I, Okuyama T, Hadi YS, Yamamoto H, Yoshida M, Watanabe H (1999) Growth stresses and strains in Acacia mangium. For Prod J 49 (2):77-81

Wardrop A, Dadswell H (1955) The nature of reaction wood. IV. Variations in cell wall organization of tension wood fibres. Australian Journal of Botany 3 (2):177-189.

Washusen R (2000) The occurrence and characteristics of tension wood and associated wood properties in Eucalyptus globulus Labill. Ph.D, The University of Melbourne, Melbourne

Washusen R (2002) Tension wood occurrence in Eucalyptus globulus Labill. II. The spatial distribution of tension wood and its association with stem form. Australian Forestry 65 (2):127-134

Washusen R (2009) The Influence of Plantation Silviculture on Tension Wood Formation. In: Apiolaza L, Chauhan SS, Walker J (eds) Revisiting Eucalypts 2009. Universit of Canterbury, Canterbury, pp 91-100

Washusen R, Ades P, Vinden P (2002) Tension wood occurrence in Eucalyptus globulus Labill. I. The spatial distribution of tension wood in one 11-year-old tree. Australian Forestry 65 (2):120-126

Washusen R, Baker T, Menz D, Morrow A (2005) Effect of thinning and fertilizer on the cellulose crystallite width of Eucalyptus globulus. Wood Sci Technol 39 (7):569-578. Washusen R, Evans R (2001a) The association between cellulose crystallite width and tension wood occurrence in Eucalyptus globulus. lawa J 22 (3):235-244

Washusen R, Evans R (2001b) Prediction of wood tangential shrinkage from cellulose crystallite width and density in one 11-year-old tree of Eucalyptus globulus Labill. Australian Forestry 64 (2):123-126

Washusen R, llic J (2001) Relationship between transverse shrinkage and tension wood from three provenances of Eucalyptus globulus Labill. Holz Roh- Werkst 59 (1-2):85-93

Washusen R, llic J, Waugh G (2003) The relationship between longitudinal growth strain and the occurrence of gelatinous fibers in 10 and 11-year-old Eucalyptus globulus Labill. Holz Roh Werkst 61 (4):299-303. 


\section{Tables}

Table 1: Number of sample trees in each silvicultural treatment (UT = Unthinned, NCT400 $=$ Non-commercial thinning 400 trees ha $^{-1}$, NCT200 $=$ Non-commercial thinning 200 trees ha $^{-1} ; \mathrm{F}=$ fertilizer)

Tabelle 1 Anzahl der untersuchten Bäume in Abhängigkeit der verschiedenen waldbaulichen Behandlungsverfahren (UT = nicht durchforstet, NCT400 = nicht kommerzielle Durchforstung 400 Bäume pro ha; NCT200= nicht kommerzielle Durchforstung 200 Bäume pro ha, $\mathrm{F}=$ Düngung)

\begin{tabular}{lllll}
\hline \multirow{2}{*}{ Treatment } & \multicolumn{2}{c}{ Total } & \multicolumn{2}{c}{ DOB $_{1.3}$} \\
\cline { 2 - 4 } & $<25 \mathrm{~cm}$ & $25-35 \mathrm{~cm}$ & $>35 \mathrm{~cm}$ & \\
\hline UT & 10 & $18+7$ & 1 & 36 \\
UTF & 15 & $18+2$ & 1 & 36 \\
NCT400 & & $18+5$ & 4 & 27 \\
NCT400F & & $18+6$ & 3 & 27 \\
NCT200 & & $18+0$ & 9 & 27 \\
NCT200F & & $18+3$ & 6 & 27 \\
\hline
\end{tabular}

Table 2: Example of measured shrinkage data at eight points on a core and predictions of wood properties from matched NIR surface scans (core No 001)

Tabelle 2 Beispiel der an acht Stellen an einem Kern gemessenen Schwindmaße und der aus den NIR-Messungen hergeleiteten Holzeigenschaften (Kern Nr. 001)

\begin{tabular}{|rrrrrr|}
\hline $\begin{array}{r}\text { Distance } \\
\text { from } \\
\text { bark }\end{array}$ & $\begin{array}{r}\text { Shrinkage } \\
12 \% \text { EMC } \\
(\mathrm{mm})\end{array}$ & $\begin{array}{r}\text { Cellulose } \\
(\%)\end{array}$ & $\begin{array}{r}\text { Density } \\
\left(\mathrm{kg} / \mathrm{m}^{3}\right)\end{array}$ & $\begin{array}{r}\text { MFA } \\
\left({ }^{\circ}\right)\end{array}$ & $\begin{array}{r}\text { MOE } \\
(\mathrm{GPa})\end{array}$ \\
\hline 21 & 11.1 & 43.3 & 794 & 10.4 & 20.5 \\
24 & 10.7 & 48.3 & 789 & 13.1 & 16.8 \\
52 & 9.3 & 46.1 & 760 & 10.6 & 19.1 \\
56 & 8.9 & 44.1 & 816 & 9.9 & 21.0 \\
84 & 8.1 & 38.5 & 606 & 16.2 & 11.3 \\
92 & 7.4 & 42.1 & 737 & 13.4 & 15.2 \\
111 & 7.2 & 46.3 & 683 & 14.3 & 14.0 \\
124 & 6.8 & 44.0 & 657 & 14.0 & 14.0 \\
\hline
\end{tabular}


Table 3: Number of trees in each treatment with shrinkages $>15 \%$ and $<15 \%$ (UT $=$ Unthinned, NCT400 $=$ Non-commercial thinning to 400 trees per ha, NCT $200=$ Noncommercial thinning to 200 trees per ha, $\mathrm{F}=$ Fertilizer applied)

Tabelle 3 Anzahl der Bäume in Abhängigkeit der verschiedenen waldbaulichen

Behandlungsverfahren mit Schwindmaßen $<15 \%$ und $>15 \%$ (UT = nicht durchforstet, NCT400 = nicht kommerzielle Durchforstung 400 Bäume pro ha; NCT200 = nicht kommerzielle Durchforstung 200 Bäume pro ha, F = Düngung)

\begin{tabular}{|lrrr|}
\hline Treatment & $\begin{array}{r}\text { Number of } \\
\text { trees with } \\
\text { shrinkage } \\
<15 \%\end{array}$ & $\begin{array}{r}\text { Number of } \\
\text { trees with } \\
\text { shrinkage } \\
>15 \%\end{array}$ & $\begin{array}{r}\text { Percentage of } \\
\text { trees with } \\
\text { shrinkage } \\
>15 \%\end{array}$ \\
\hline UT & 32 & 2 & 7.1 \\
UTF & 29 & 6 & 21.4 \\
NCT200 & 19 & 7 & 25.0 \\
NCT200F & 21 & 6 & 21.4 \\
NCT400 & 26 & 1 & 3.6 \\
NCT400F & 20 & 6 & 21.4 \\
Total & 147 & 28 & 16.0 \\
\hline
\end{tabular}

Table 4: SilviScan mean maximum and minimum values for the 20 wood cores Tabelle 4 Mittlelwerte, Größt- und Kleinstwerte der 20 Bohrkerne bestimmt mittels SilviScan

\begin{tabular}{|lrrr|}
\hline & $\begin{array}{r}\text { Density } \\
\left(\mathrm{kg} / \mathrm{m}^{3}\right)\end{array}$ & MFA $\left(^{\circ}\right)$ & $\begin{array}{r}\mathrm{MOE} \\
(\mathrm{GPa})\end{array}$ \\
\hline Mean & 783 & 10.3 & 18.6 \\
Max & 1216 & 47.5 & 36.7 \\
Min & 293 & 2.0 & 5.4 \\
\hline
\end{tabular}


Table 5: Pearson correlation matrix results for shrinkage at $12 \% \mathrm{MC}$ AR, cellulose content, MFA, density and MOE for the equally weighted shrinkage data set. Level of significance: ${ }^{*}=\mathrm{P}<0.05,{ }^{* *}=\mathrm{P}<0.01,{ }^{* * *}=\mathrm{P}<0.001 . \mathrm{N}=79$

Tabelle 5 Pearson Korrelationskoeffizienten zwischen dem Schwindmaß bei $12 \%$

Holzfeuchte nach Dampfkonditionierung, dem Cellulosegehalt, dem

Mikrofibrillenwinkel, der Dichte und des E-Moduls auf Basis der gleich gewichteten

Schwindmaße. Signifikanzniveau: ${ }^{*}=\mathrm{P}<0,05,{ }^{* *}=\mathrm{P}<0,01, * * *=\mathrm{P}<0,001 . \mathrm{N}=79$

\begin{tabular}{|lrrrr|}
\hline & Cellulose & Density & MFA & MOE \\
\hline Tangential & $0.76^{* *}$ & $0.67^{* \star}$ & $-0.67^{\star *}$ & $0.69^{* *}$ \\
Shrinkage & & & & \\
Cellulose & & $0.66^{* *}$ & $-0.65^{\star *}$ & $0.67^{\star *}$ \\
Density & & & $-0.85^{\star *}$ & $0.92^{\star *}$ \\
MFA & & & & $-0.97^{\star *}$ \\
\hline
\end{tabular}

Table 6: Pearson correlation matrix results for shrinkage at $12 \%$ MC AR, predicted cellulose content, MFA, density and MOE for the full data set. Level of significance: ${ }^{*}=\mathrm{P}$ $<0.05,{ }^{* *}=\mathrm{P}<0.01,{ }^{* * *}=\mathrm{P}<0.001 . \mathrm{N}=1,386$

Tabelle 6 Pearson Korrelationskoeffizienten zwischen dem Schwindmaß bei 12\%

Holzfeuchte nach Dampfkonditionierung, dem Cellulosegehalt, dem

Mikrofibrillenwinkel, der Dichte und des E-Moduls auf Basis aller Daten.

Signifikanzniveau: ${ }^{*}=\mathrm{P}<0,05,{ }^{* *}=\mathrm{P}<0,01, * * *=\mathrm{P}<0,001 . \mathrm{N}=1386$

\begin{tabular}{|lrrrr|}
\hline & Cellulose & Density & MFA & MOE \\
\hline Tangential & $0.45^{\star *}$ & $0.51^{* *}$ & $-0.52^{\star *}$ & $0.55^{* *}$ \\
Shrinkage & & & & \\
Cellulose & & $0.38^{* *}$ & $-0.42^{\star *}$ & $0.45^{\star *}$ \\
Density & & & $-0.83^{\star *}$ & $0.91^{* *}$ \\
MFA & & & & $-0.97^{\star *}$ \\
\hline
\end{tabular}

Table 7: Forward stepwise multiple regressions for predicting tangential shrinkage after reconditioning to $12 \% \mathrm{MC}$ using the equally weighted shrinkage data set (Model 1) and using the full data set (Model 2)

Tabelle 7 Schrittweise multiple Regressionen mit Vorwärtsselektion zur Bestimmung des tangentialen Schwindmaßes nach Rücktrocknung auf 12 \% Holzfeuchte anhand der gleich gewichteten Schwindmaße (Modell 1) und anhand aller Daten (Modell 2)

\begin{tabular}{|lrr|}
\hline Model 1 & Beta & $\mathrm{p}$-value \\
\hline Constant (intercept) & -26.11 & \\
Cellulose content & 0.679 & $<0.001$ \\
MOE & 0.382 & $<0.001$ \\
\hline Model 2 & & \\
\hline Constant (intercept) & -3.917 & \\
Cellulose content & 0.192 & $<0.001$ \\
MOE & 0.274 & $<0.001$ \\
\hline
\end{tabular}




\section{Figure Captions}

Fig.1: Core marked into 4 quarters with respective mid-points marked with a dot

Fig.2: Dried core sample with 8 marked measured points. Crosses indicate observed points of maximum tangential shrinkage points. Dots indicate the mid-points of each quarter

Fig.3: Results of the cross validation for MFA (a), density (b) and MOE (c)

Fig.4: Variation of predicted cellulose content, density, MFA and MOE from bark to pith in core No. 209

Fig.5: Plot of the observed and predicted tangential shrinkage to $12 \% \mathrm{MC}$ AR using the regression Model 1applied on the equally weighed data set

Fig.6: Plot of the observed and predicted values of tangential shrinkage to $12 \%$ MC AR for the regression Model 1 applied on the whole data set

Fig.7: Variation of predicted tangential shrinkage in 4 cores indicating nonrecoverable collapse

Abb.1 In vier Teile unterteilter Kern. Der Punkt gibt die Mitte eines jeden Viertels an

Abb. 2 Getrockneter Prüfkörper mit acht markierten Messstellen. Die 4 Punkte und 4 Kreuze kennzeichnen die Stellen mit dem höchsten erkannten Schwindmaß. Die Punkte stellen die Mitte eines jeden Viertels dar.

Abb. 3 Zusammenhang zwischen mit SilviScan gemessenen und bestimmten Werte des a) Mikrofibrillenwinkel s(MFA), b)der Dichte und c)des Elastizitätsmoduls (MOE)

Abb. 4 Verlauf des bestimmten Zellulosegehalts, der Dichte, des Mikrofibrillenwinkels und des Elastizitätsmoduls von der Rinde zur Markröhre in Kernnr. 209

Abb. 5 Zusammenhang zwischen gemessenem und mittels Regressionsmodell 1 und dem gleich gewichteten Datensatz bestimmtem tangentialen Schwindmaß nach Rücktrocknung auf $12 \%$ Holzfeuchte

Abb. 6 Zusammenhang zwischen gemessenem und mittels Regressionsmodell 1 auf Basis aller Daten Datensatz bestimmtem tangentialen Schwindmaß nach Rücktrocknung auf $12 \%$ Holzfeuchte

Abb. 7 Verlauf des bestimmten tangentialen Schwindmaßes bei 4 Kernen, der auf nicht rückverformbaren Kollaps hinweist 


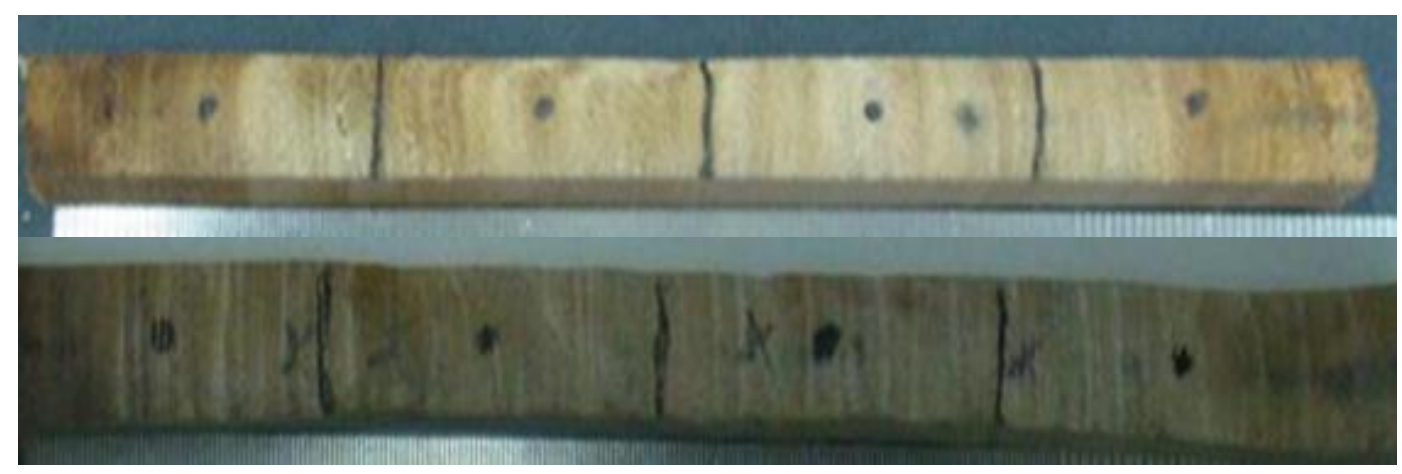




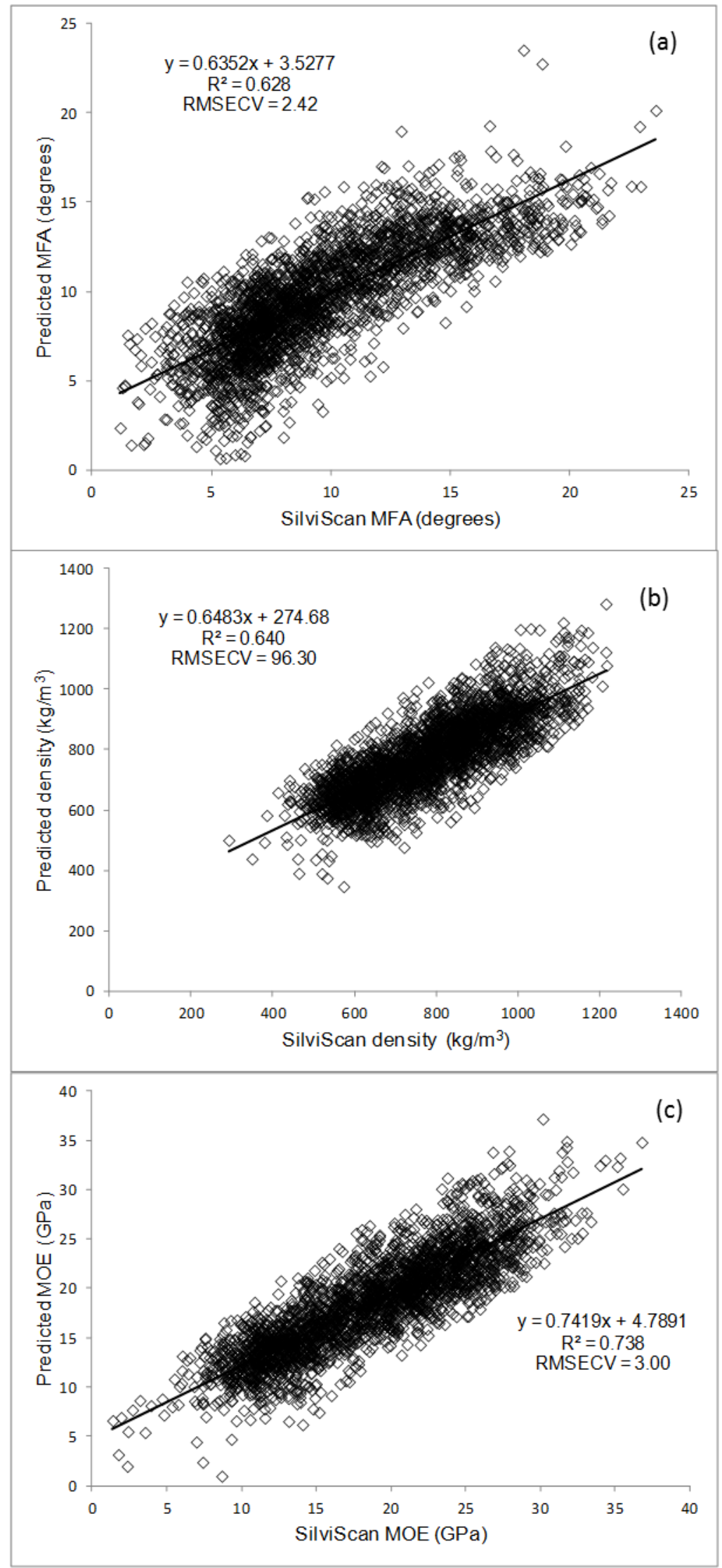




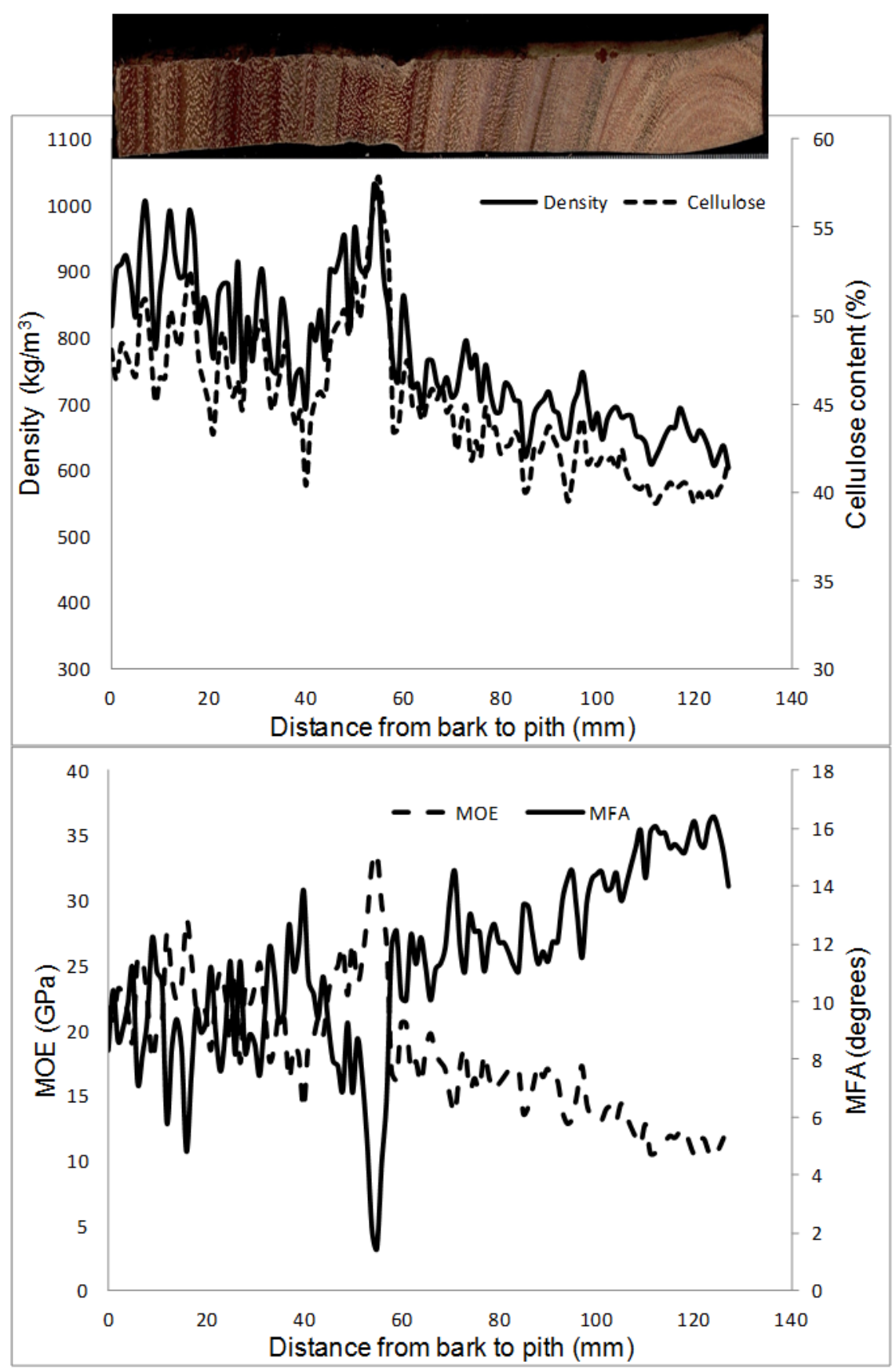




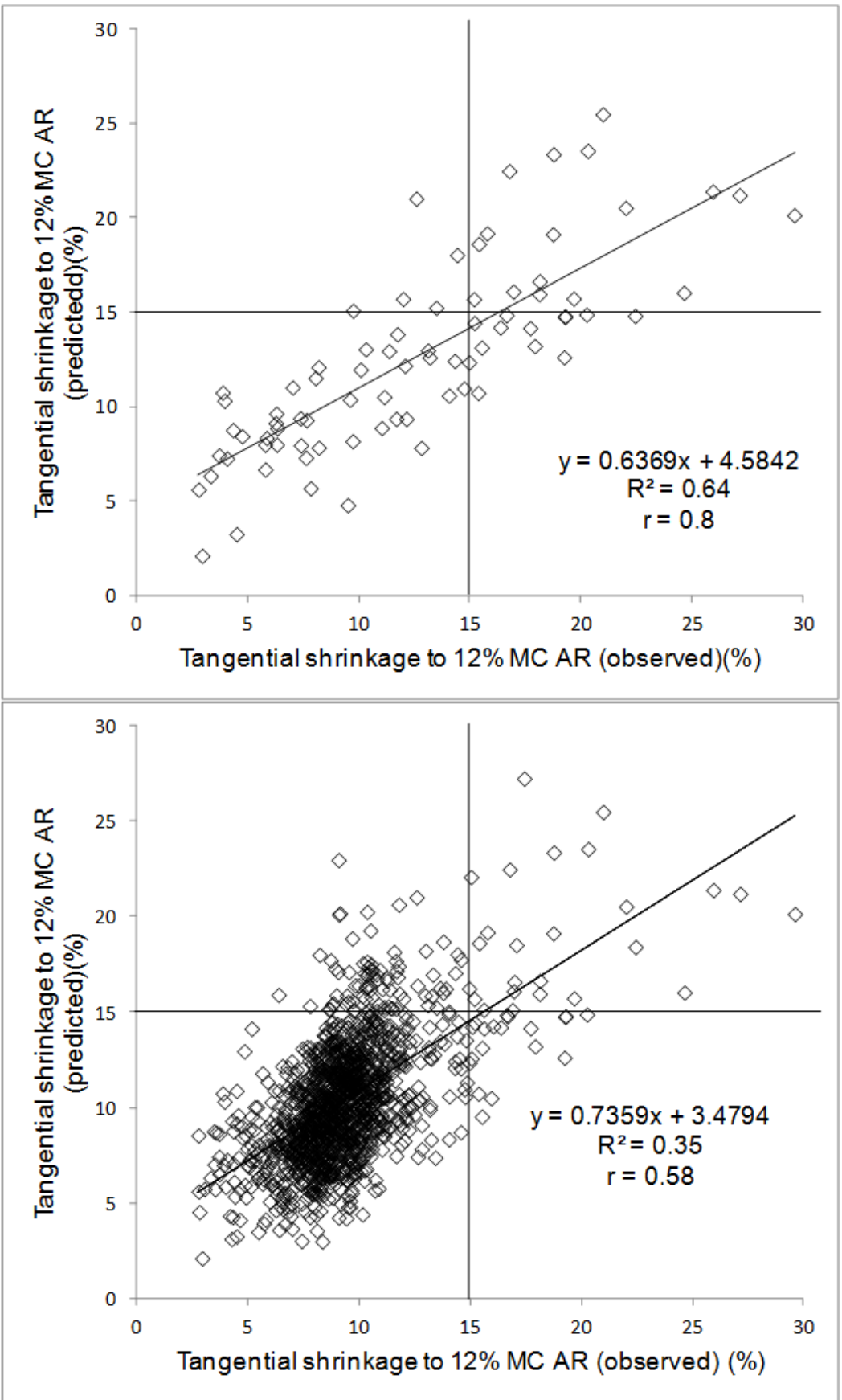




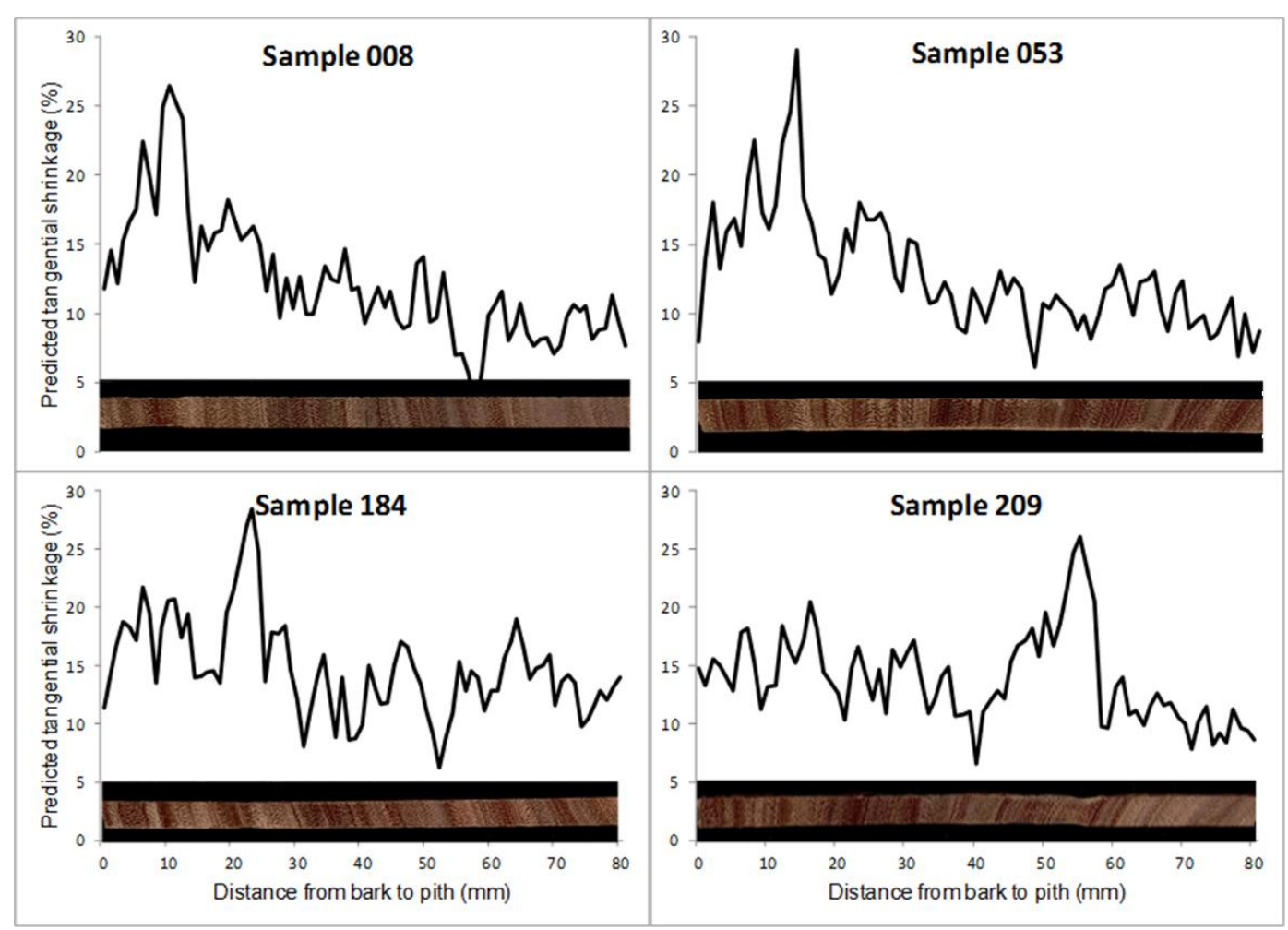




\section{University Library}

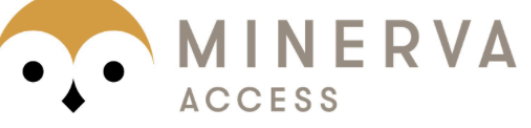

A gateway to Melbourne's research publications

Minerva Access is the Institutional Repository of The University of Melbourne

Author/s:

Wentzel-Vietheer, M;Washusen, R;Downes, GM;Harwood, C;Ebdon, N;Ozarska, B;Baker, T

Title:

Prediction of non-recoverable collapse in Eucalyptus globulus from near infrared scanning of radial wood samples

Date:

2013-11-01

Citation:

Wentzel-Vietheer, M., Washusen, R., Downes, G. M., Harwood, C., Ebdon, N., Ozarska, B. \& Baker, T. (2013). Prediction of non-recoverable collapse in Eucalyptus globulus from near infrared scanning of radial wood samples. EUROPEAN JOURNAL OF WOOD AND WOOD PRODUCTS, 71 (6), pp.755-768. https://doi.org/10.1007/s00107-013-0735-y.

Persistent Link:

http://hdl.handle.net/11343/282790 